\title{
Legitimacy, Discretion, and the Concept of Rights
}

\author{
Robert L. Rabin†
}

In order to understand the role of rights in the development of the Administrative State, it is essential to look at a century of administrative history-rather than limiting one's view to the fifty years since the birth of the New Deal. Taking the past century as my time-frame, I want to survey briefly three epochs: the Populist-Progressive era, ${ }^{1}$ the New Deal, and the Public Interest era. ${ }^{2}$ After identifying the major concerns expressed in the political debate over regulatory reform in each period, I will try to forge a link between regulatory politics and the central preoccupations of the judiciary. In doing so, I hope to shed some light on the importance that courts-particularly, the Supreme Court-attached to the conception of rights as the Administrative State evolved.

In my view, two principal themes are evident in judicial treatment of regulatory issues during the past century: Courts have been preoccupied with assessing legitimacy and controlling discretion. ${ }^{3}$ Each of these themes has, as one of its concerns, a connection with conventional notions of rights. Just as the themes are distinct, however, so are the correlative rights conceptions. The legitimacy theme-that is, judicial efforts to define the appropriate ambit of agency power-was elaborated against the backdrop of a substantive conception of "rights" expressed in a private order-

$\dagger$ Professor of Law, Stanford University. I would like to express my appreciation to the Russell Sage Foundation for its support of my work on the historical development of the federal administrative system. This essay is based on that project.

1. For present purposes, I am considering the Populist and Progressive eras together, because my focus is exclusively on the politics of regulatory reform at the national level, and my intention is only to develop the historical context necessary to an understanding of the role of the federal government in limiting private rights. I recognize that the Populist and Progressive movements had very different origins, bases of support, and political agendas-and that each movement was itself governed by a variety of goals in the state and local political arenas that differed markedly from the programs pursued at the national level.

There is a voluminous literature on the movements. Much of the recent scholarship was stimulated by the reappraisal of the eras, in R. HOFSTADTER, THE AGE OF REFORM (1955). See sources cited infra note 5 (discussing bibliography).

2. I attach this label to the period of regulatory reform activity, characterized by the consumer and environmental movements, that began in the late 1960's. While so-called public interest regulatory initiatives and litigation were central features of the era, I adopt the label principally for convenience-and because no generally accepted name has been bestowed on the period.

3. To state the distinction succinctly: By "assessing legitimacy" I mean an inquiry directed at determining the appropriate sphere of administrative activity, and by "controlling discretion" I have in mind the methods by which the courts assure rational decisionmaking within the sphere of legitimate agency power. 
ing model of economic relations. ${ }^{4}$ By contrast, the judicial focus on issues of discretion-specifically, judicial techniques for monitoring the agency decisionmaking process-has, at times, been associated with a procedural version of "rights" analysis; namely, the imposition of a trial-type decisionmaking model to assure rational agency behavior.

My contention is that the past century has witnessed an evolutionary process in which controlling discretion has become the principal concern of the courts, as legitimacy issues were put to rest. Concomitantly, to the extent that rights analysis retains any importance, it is the procedural version of the concept that has continuing vitality. But the picture is somewhat more complex than this summary assertion might suggest. For my basic contention is that the conception of rights, even in its procedural guise, is on the periphery of the current preoccupation with control of discretion-as I hope to demonstrate in the following brief excursion through a century of political and judicial developments.

\section{The Populist-Progressive Era}

As far as federal regulatory legislation is concerned, the era preceding the New Deal was characterized by the fundamental premise that governmental intervention in the private ordering system ought to be limited to occasional policing activity. ${ }^{\mathrm{B}}$ A smoothly functioning market was viewed as the best means for maximizing social welfare. Such agencies as the Interstate Commerce Commission (ICC), the Bureau of Chemistry (forerunner of the Food and Drug Administration) and the Meat Inspectorate in the Department of Agriculture, and the Federal Trade Commission (FTC), were established under the guiding assumption that the private market model would work, if only its excesses could be eliminated. Each of these agencies was assigned the role of policing and regulating "wrongful" or "unreasonable" conduct in order to re-establish a sense of equilibrium in the network of privately negotiated commercial dealings.

The first of the federal regulatory commissions, the ICC, was established in 1887 after a decade of debate over the appropriate scope of railroad regulation. Each of the contending interests-railroads, shippers,

4. This economic perspective on legitimacy is distinct from the political conception traditionally associated with the non-delegation doctrine, which rests principally on separation of powers concerns. See J. FREEDMAN, CRISIS AND LEGITIMACY 15-94 (1978).

5. Again, I want to emphasize that my remarks are directed to reform efforts at the national level. The goals of the Populist movement at the state level appear to have rested on quite different assumptions about the proper scope of governmental activity. See L. GOODWYN, THE POPULIST MOMENT (1978).

Moreover, it seems clear that Progressive reform initiatives at the state and local level exhibited a wide variety of often contradictory ideological premises. For a discussion of the conflicting ideological themes and historical interpretations of Progressive thought, see Rodgers, In Search of Progressivism, REVS. AM. HIST., Dec. 1982, at 113. 
merchants, and farmers-sought to "rationalize" competition in accordance with its own economic needs. The result was a weak, and in some instances ambiguous, statute prohibiting discriminatory trade practices. ${ }^{\circ}$ Similarly, the Bureau of Chemistry officials and meat inspectors were legislatively mandated to police unconscionable business activities-human health risks that arose from lack of consumer information (which, in the current idiom, would be identified as one variety of "market failure"). And, of course, the FTC was given responsibility for attacking what was regarded by many Progressives as the prototypical instance of market dysfunction: the growth of monopoly power. ${ }^{7}$ While the responsibilities of these agencies were by no means parallel-ranging across investigating, inspecting, and prosecuting roles-they shared a central focus on prohibition of "excesses" in the marketplace.

In the beginning, then, regulatory legislation was seen as a corrective. Business leaders eager to engage in cartel-like activities favored a passive regulatory presence--an environment in which they could enter into private cooperative agreements with impunity-rather than an active governmental role. And for those who feared industrial dominance, agencies were a means of policing overzealous commercial interests that sought unfair advantage under the existing rules.

Subscribing to this restrictive view of the appropriate conditions for governmental intervention, the courts were preoccupied with assuring the legitimacy of agency assertions of power. It was not just that regulatory agencies were a brand-new phenomenon-which they were, of course-but also that the very notion of buttressing the market economy from the outside, so to speak, was entirely novel. ${ }^{8}$ Thus, many of the leading Supreme Court decisions, providing the interpretative foundations for the new regulatory legislation, were devoted to a vigorous policing of the substantive boundaries of the agencies. ${ }^{9}$

Indeed, read apart from the political history of the time, many of these

6. There is a vast literature on the formation of the Interstate Commerce Commission (ICC). An excellent recent source is S. SKOWRONEK, BUILDING A NEW AMERICAN STATE: THE EXPANSION OF NATIONAL ADMINISTRATIVE CAPACTIES, 1877-1920, at 123-50 (1982). Between 1903 and 1920, Congress passed a succession of amendments, expanding the powers of the ICC to the point at which the agency eventually was given rather substantial planning authority. See id. at 249-84.

7. The Federal Trade Commission (FTC) was also given more general authority to police unfair trade practices. The best early study of the FTC is G. HENDERSON, THE FEDERAL TRADE COMMISSION (1924).

8. The agencies established prior to 1887 were principally intended to provide public services, distribute government largess, and collect taxes. For a concise historical treatment, see Wilson, The Rise of the Bureaucratic State, in PERSPECTIVES ON THE ADMINiSTRATIVE PROCESS 16 (R. Rabin ed. 1979).

9. Notwithstanding the voluminous literature on the non-delegation doctrine, the principal congressional technique for restricting agency power has been the Court's repeated tendency to construe narrowly agency enabling legislation. 
cases seem remarkably uncharitable. Consider, for example, FTC v. Gratz, ${ }^{10}$ in which the Court read section 5 of the FTC Act, ${ }^{11}$ prohibiting "unfair methods of competition in commerce," as limiting the FTG to prosecution of those anti-competitive acts condemned at common law. ${ }^{12}$ Or, United States v. Johnson, ${ }^{13}$ in which defendant had knowingly labeled his patent medicine as a cancer cure, and the Court nonetheless read the prohibition on misbranding in the Food and Drug Act to cover only false statements regarding ingredients and not effects-despite a statutory prohibition on misbranding "which [is] false or misleading in any particular."14 Or, to provide a final example, the leading case of ICC v. Alabama Midland Railway, ${ }^{15}$ in which the Court overturned the ICC's effort to give substance to a weak legislative prohibition of rate discrimination between long-haul and short-haul trips-a regulatory effort aimed at a principal source of the hostility created by the railroad's competitive practices. ${ }^{16}$

The linkage between this overriding concern with the legitimacy of agency power-the chipping away at the edges of the agency's substantive mandate-and the conception of rights is fairly straightforward. The concern about individual commercial autonomy and an unimpeded flow of market transactions, which is at the core of the conventional substantive notion of rights, was a key factor in leading the Court to limit the field of each agency's authority so severely. ${ }^{17}$ Thus, the "rights" model loomed large in judicial thinking during the Populist-Progressive period of regulatory politics.

10. 253 U.S. 421 (1920).

11. Pub. L. No. 63-203, § 5, 38 Stat. 717,719 (1914) (codified as amended at 15 U.S.C. $§ 45$ (1982)).

12. See also FTC v. American Tobacco Co., 264 U.S. 289 (1924) (narrowly construing agency's investigatory powers); FTC v. Raladam Co., 283 U.S. 643 (1931) (holding that agency had to establish harm to competitors, not merely consumers, to make out statutory violation). Congress reacted to Raladam by passing the Wheeler-Lea Act, Pub. L. No. 75-447, 52 Stat. 111 (1938) (codified as amended at 15 U.S.C. $\S \S 41,44,45,52-58$ (1982)), overturning the decision.

13. 221 U.S. 488 (1911).

14. Pub. L. No. 59-384, § 8, 34 Stat. 768, 770 (1906) (repealed 1938). Congress reacted to Johnson by passing the Sherley Amendment, Pub. L. No. 62-301, 37 Stat. 416 (1912) (repealed 1938), overturning the holding.

15. 168 U.S. 144 (1897).

16. Alabama Midland is one of a series of narrow constructions of the Interstate Commerce Act that eventually led to the congressional amendments of the statute. The cases are discussed in $\mathrm{S}$. SKOWRONEK, supra note 6 , at 150-60.

17. It was not, however, the only factor. Beginning in Chicago, Mil. \& St. P. Ry. v. Minnesota, 134 U.S. 418 (1890), the Court asserted its authority to conduct de novo review of agency-established transportation rates. The exercise of de novo review in this and later cases undoubtedly reflected judicial suspicion of agency decisionmaking processes distinct from an abstract concern about safeguarding property interests. 


\section{The New Deal}

The dominant political impulse in the New Deal was sharply at odds with that of the preceding era. ${ }^{18}$ Shaken by the Depression, the political leadership of the country no longer accepted the premises of the private ordering model as providing a sufficient foundation for a socioeconomic system. Instead, the Roosevelt Administration began to experiment with a mixed bag of regulatory reforms aimed both at achieving economic recovery and bolstering economic security. ${ }^{19}$ Agency programs were established that could be taken to reflect a number of, almost certainly, irreconcilable convictions: that governmental planning, in cooperation with large-scale business, labor, and consumer groups, was the best means of achieving the public interest in economic recovery and security; that governmental coordination of an essentially privately-run system of business cartels was most likely to effect a return to economic well-being; and that governmental intervention to re-establish a competitive society dominated by small businesses would counter the ill effects of fifty years of growing industrial concentration.

While these ideologies were by no means consistent, they did yield a virtual consensus on one point: that a free market economy, subject only to relatively minor policing activities, was an anachronism and a menace to long-term social welfare. Out of this conviction grew new regulatory programs in vital economic areas such as banking, agriculture, social security, and labor relations. ${ }^{20}$

As new relationships were created between government, the private business sector, and the individual, a wide array of agencies were given, for the first time, genuinely managerial-type responsibilities. Indeed, in his most ambitious move, Roosevelt proposed, and Congress enacted, the National Industrial Recovery Act (NIRA), ${ }^{21}$ providing for Codes of Fair Competition-governing prices, wages, hours, advertising practices, and such-which were to be promulgated by industrial trade groups and implemented by a newly-established federal agency. ${ }^{22}$ Perhaps more than

18. But see Hawley, Herbert Hoover, the Commerce Secretariat, and the Vision of an "Associative State," 1921-1928, 61 J. AM. HIST. 116 (1974-75) (discussing governmental encouragement of the trade association movement in 1920's).

19. The diverse programs and their often contradictory ideological underpinnings are well discussed in E. HAWLEY, THE NEW DEAL AND THE PROBLEM OF MONOPOLY (1966). Like the earlier movements, the New Deal is notable for the absence of a coherent, unified reform strategy. See supra notes 1,5 .

20. For general discussions of the New Deal programs, see, e.g., W. LEUCHTENBURG, FRANKLIN D. ROOSEVELT AND THE NEW DEAL (1963), and P. CONKIN, THE NEW DEAL (2d ed. 1975). The standard early account dividing the New Deal into two phases, an early period concerned with economic recovery and a later period emphasizing economic security, is B. RAUCH, THE HISTORY OF THE NEW DEAL: 1933-1938 (1944).

21. Pub. L. No. 73-67, 48 Stat. 195 (1933).

22. See E. HAWLEY, supra note 19 , at 19-146. 
any other single New Deal program, the NIRA heralded a new, expansive conception of activist government.

Government agencies now assumed the functions of Manager-Benefactor, rather than merely serving as Investigator-Enforcer. As might be expected, such a dramatic shift in regulatory ideology, fitfully unveiled in the New Deal programs, once again brought issues of the legitimacy of agency power to the forefront. ${ }^{23}$ The private ordering model of the economy, as a constraint on the regulatory authority that might legitimately be vested in an agency, had one last stand in the courts. And indeed, in the landmark Schechter case, ${ }^{24}$ the substantive conception of rights achieved a stunning victory, before its decisive retreat beyond the borders of the new Administrative State.

The Schechter case, testing the constitutionality of the NIRA, in fact, stands at the crossroads-marking off the intersection of the two major themes in judicial discourse that form the focus of this essay: assessing legitimacy and controlling discretion. In striking down the Act, the Court invoked the non-delegation doctrine on three grounds: the unbounded substantive mandate (allowing virtually every aspect of business conduct to be regulated in the Codes of Fair Competition), the improper delegation to private parties (giving industry groups the main role in establishing the Codes), and the failure to provide adequate procedural safeguards for formulating policy. Clearly, the first two grounds rely heavily on a model of economic relations-a substantive rights model - that places high value on freedom from governmental interference and limited restrictions on private property. At the same time, the Court's third concern rests on its perception of the need to monitor effectively the rationality of administrative policy; in other words, control of agency discretion is the guiding force behind the demand for adequate procedural safeguards.

Interestingly, Schechter is the concluding chapter in the half century of concern about legitimacy. Just as the Court was subsequently to abandon its harsh treatment of the agencies of the Populist-Progressive era, so too did the post-Schechter judiciary come to terms with the New Deal conception of governmental activism. The Court's propensity to question the legitimacy of agency authority was put to rest-and correlatively, the substantive conception of "rights" linked, as it was, to the private ordering model fell into desuetude. Instead, the major concern of the post-Schechter

23. On the eve of the New Deal, the Investigator-Enforcer role of agencies had become well accepted. In part, the Court had been "educated" by congressional responses to its strict constructionism. See supra notes $12,14,16$.

24. A.L.A. Schechter Poultry Corp. v. United States, 295 U.S. 495 (1935). In Panama Ref. Co. v. Ryan, 293 U.S. 388 (1935), United States v. Butler, 297 U.S. 1 (1936), and Carter v. Carter Coal Co., 298 U.S. 238 (1936), the Court similarly expressed its hostility towards Roosevelt's New Deal regulatory legislation. 
Gourt became the control of administrative discretion.

But the new status accorded to issues of agency discretion did not, in turn, create an activist judiciary. A more subtle interplay occurred. For the New Deal also heralded the rise of faith in expertise. ${ }^{25}$ And as a consequence, while control of discretion as an issue became the Court's major preoccupation, the judicial mood was distinctly deferential. In the great cases of the post-New Deal era-Morgan ${ }^{26}$ Hearst $_{,}{ }^{27}$ Chenery, ${ }^{28}$ and Universal Camera, ${ }^{29}$ to cite a few representative examples-the Court was constantly involved in defining its own role in implementing a regulatory scheme, but invariably ended up extolling the virtues of bureaucratic specialization and professionalism.

Thus, as the era progresses, the "rights" tradition recedes into the past. The substantive rights model relinquishes its dominant influence with the dissolution of the Schechter Court. And the procedural version of the rights concept-the trial-type hearing as a model for controlling discretion-lays dormant in an era of deference to administrative expertise. ${ }^{30}$

\section{The Public Interest Era}

By 1970, it was possible to identify a new wave of regulatory reform that was distinct in character from that of the New Deal. The Depression, of course, had been the precipitating event that triggered the New Deal. By contrast, the reform impulse that began to build in the late 1960's came at a time of economic prosperity. Nonetheless, it was a deeply troubled period. Vietnam cast a pall over everyday life. Race relations seethed with unresolved tensions. And domestically, a host of concerns arose that had little to do with economic well-being. Long-term health and safety,

25. For a classic exposition, see J. LANDIS, THE ADMINISTRative Process (1938). In fact, Progressives had shown a similar faith in expertise. See, e.g., P. NONET, ADMINISTRATIVE JUSTICE 16-37 (1969) (discussing administration of workman's compensation legislation); S. HAYS, CONSERVATION AND THE GOSPEL OF EFFICIENCY: THE PROGRESSIVE CONSERVATION MOVEMENT, 1890-1920 (1959) (analyzing origins of conservation movement). But this faith had not been widely adopted by the courts.

26. United States v. Morgan, 313 U.S. 409 (1941) (Morgan IV).

27. NLRB v. Hearst Publications, Inc., 322 U.S. 111 (1944).

28. SEC v. Chenery Corp., 332 U.S. 194 (1947) (Chenery II).

29. Universal Camera Corp. v. NLRB, 340 U.S. 474 (1951).

30. I would note two important qualifications, however. First, the procedural version of the rights concept was, in fact, influential in the legislative forum; witness the provisions for agency adjudication in the Administrative Procedure Act, 5 U.S.C. $\$ \S 554,556,557$ (1982), enacted in 1946, as well as in various agency enabling acts. Second, there are constitutional "right to hearing" cases decided during the period that recognize procedural-as well as substantive-_"rights," modelled on traditional protections of property interests. For a discussion, see Van Alstyne, The Demise of the Right-Privilege Distinction in Constitutional Law, 81 HARV. L. REV. 1439 (1968). But the constitutional "right to hearing" cases do not, for the most part, involve regulatory programs of the kind we are considering. Rather, these cases arise in areas such as occupational licensing and government job security, which bear stronger resemblance to private contract and property relations than to bureaucratic policymaking. 
preservation of natural sites and species, and a variety of similar problems attained considerable public visibility, and were translated into political demands that came to be labelled "quality of life" concerns. This cluster of issues sparked a vigorous debate over the propriety of pluralistic politics and the meaning of "the public interest," and in turn initiated a new wave of governmental activism. ${ }^{31}$

The National Environmental Policy Act (NEPA), passed in 1969, is a classic illustration of the new reforms. It includes a general proclamation that concern for the quality of the environment is a top priority of the federal government, and operationally, that every federal agency is to take account of environmental impacts in making decisions that might affect the human environment. ${ }^{\$ 2} \mathrm{~A}$ similar thrust-toward quality of life concerns-is found in the other major regulatory legislation of the period, such as the Glean Air Act, Federal Water Pollution Control Act, Occupation Safety and Health Act, Consumer Product Safety Act, National Traffic and Motor Vehicle Safety Act, as well as in the establishment of new regulatory agencies to administer these congressional initiatives. ${ }^{33}$

Despite the sharp departure in substantive concerns, the new reform legislation did not rekindle old fears about the legitimacy of agency power. No one seriously questioned the authority of Congress to provide the Environmental Protection Agency with a broad mandate to set air pollution control standards, or the propriety of legislation that gave the Occupation Safety and Health Administration (OSHA) power to establish a network of occupational health and safety standards. On the contrary, the tacit assumption was that quality of life reforms were exclusively a question of efficacious policy, rather than a cause for re-examining the role of regulatory agencies in the constitutional framework. This easy acquiescence on the issue of agency power reinforced the course of late New Deal thought: in the Administrative State, there are no practical limitations on the potential scope of agency authority. ${ }^{34}$

At the same time, however, the courts developed a strikingly new atti-

31. For a thoughtful critique of pluralist politics, see T. LOW, THE END OF LIBERALISM (2d ed. 1979).

32. For discussion of the act, see R. LiRoff, A NATIONAL POLIGY FOR THE ENVIRONMENT: NEPA AND ITS AFTERMATH (1976). The requirement of an environmental impact statement is found in $\S 102(2)(C)$ of the Act, 42 U.S.C. $\S 4332(2)(C)$ (1976).

33. Consider, for example, the Environmental Protection Agency, established in 1970 to implement and enforce much of the existing environmental protection legislation. NEPA itself provided for the Council on Environmental Quality, an Executive agency charged with coordinating and advisory functions.

34. I would emphasize, however, that the diminished concern about legitimacy does not denote the wholesale extinction of a substantive conception of rights-that is, that all individually-held entitlements are contingent. See supra note 30 . Rather, I am suggesting that the private ordering model - so central to pre-New Deal thinking-did not operate as a constraint on the kinds of functions that agencies might undertake. 
tude towards control over agency discretion. Abandoning the deferential mood of the 1940's and 1950's, the judiciary became preoccupied with "the hard look." tion, Judge Bazelon noted:

We stand on the threshold of a new era in the history of the long and fruitful collaboration of administrative agencies and reviewing courts. For many years, courts have treated administrative policy decisions with great deference, confining judicial attention primarily to matters of procedure. On matters of substance, the courts regularly upheld agency action, with a nod in the direction of the "substantial evidence" test, and a bow to the mysteries of administrative expertise. Courts occasionally asserted, but less often exercised, the power to set aside agency action on the ground that an impermissible factor had entered into the decision, or a crucial factor had not been considered. Gradually, however, that power has come into more frequent use, and with it, the requirement that administrators articulate the factors on which they base their decisions. ${ }^{36}$

Why did this distinctive shift in attitude occur? At least two reasons seem central to an understanding of the new tendency to subject regulatory decisions to careful scrutiny. First, the new wave of regulatory reform created agencies whose subject matter was often characterized by indeterminacy of harm (or, correspondingly, the new quality of life concerns often expanded the list of considerations that established agencies were required to take into account). This problem of indeterminacy was sometimes raised by scientific uncertainty - as in the hybrid rulemaking cases dealing with issues of pollution control or nuclear safety. ${ }^{37}$ In another class of cases, the indeterminacy problem arose because of difficulties in quantifying intangible values-illustrated by classic licensing controversies like Scenic Hudson. ${ }^{38}$ Whether scientific uncertainty or intangible values were involved, the courts were now uneasy about the old claims for deference to expertise; the received wisdom about expertise seemed open to question.

Second, the course of recent history had taken its toll. Vietnam, minor-

35. The term is Judge Harold Leventhal's. See Greater Boston Television Corp v. FCC, 444 F.2d 841, 851 (D.C. Cir. 1970), cert. denied, 403 U.S. 923 (1971), where he applied it to agency decisionmaking responsibilities. But the "hard look" concept has been taken to be equally applicable to courts in exercising judicial review of agency decisions.

36. Environmental Defense Fund, Inc. v. Ruckelshaus, 439 F.2d 584, 597 (D.C. Cir. 1971).

37. See Yellin, High Technology and the Courts, 94 HARV. L. REV. 489, 494-500 (1981).

38. Scenic Hudson Preservation Conf. v. FPC, 354 F.2d 608 (2d Cir. 1965) (Scenic Hudson I) (construction of hydroelectric power plant at point of scenic and historical value on the Hudson River); Scenic Hudson Preservation Conf. v. FPC, 453 F.2d 463 (2d Cir. 1971) (Scenic Hudson II), cert. denied, 407 U.S. 926 (1972). 
ity unrest, Naderism, and congeries of other factors had contributed to a dramatic loss of faith in experts-indeed, in the world of "officials"- that had become pervasive by 1970 . Skepticism about the rational implementation of governmental policy was rampant. The judiciary was not insulated from these corrosive tendencies.

Thus, a real preoccupation with controlling discretion arose, and concomitantly, judicial review decisions began to manifest a tendency to search for The Ultimate Rational Process. In fact, throughout the 1970's the federal judiciary oscillated between two discrete tendencies, which might be characterized as a Demand for Truth, evinced through remands requiring more and better data in a search for The Right Answer; and an Assurance of Good Faith, satisfied by sufficient data to demonstrate a Best Effort Under the Circumstances. ${ }^{38}$

This oscillation is evident in the leading administrative law cases decided in the Public Interest era. For present purposes, a brief catalogue, with somewhat greater attention to one entry, will have to suffice.

(1) In the area of informal adjudication, compare Overton Park, ${ }^{40}$ requiring what amounts to virtually de novo review in the trial court, ${ }^{41}$ with Camp v. Pitts, ${ }^{42}$ limiting review to the contemporaneous administrative record.

(2) In the informal rulemaking area, compare the D.C. Circuit's hybrid rulemaking cases, ${ }^{43}$ requiring procedural safeguards beyond the noticeand-comment provisions of the Administrative Procedure Act (APA), ${ }^{\mathbf{4}}$ with Vermont Yankee, ${ }^{45}$ interpreting the APA in a more literal fashion. ${ }^{46}$

39. These tendencies are not polar extremes. Indeed, both positions expressed an activist mood regarding the role of the judiciary. A broader continuum might be defined in which a Demand for Truth and an Assurance of Good Faith are intermediate points on a scale featuring a De Novo Review position at one end and a Deference to Expertise position at the other.

Because of space limitations, I am ignoring the important distinction between controlling discretion through requirements imposed on internal agency processes and controlling discretion through modulation of judicial scrutiny. The two techniques may or may not be employed in tandem.

40. Citizens to Preserve Overton Park v. Volpe, 401 U.S. 402, 420-21 (1971).

41. 335 F. Supp. 873 (W.D. Tenn. 1972) (on remand). The trial consumed 25 days and involved the submission of 240 exhibits and 287 pages of written briefs. Id. at 878 .

42. 411 U.S. 138, 141-43 (1973).

43. See, e.g., Kennecott Copper Corp. v. EPA, 462 F.2d 846, 850-51 (D.C. Cir. 1972); International Harvester v. Ruckelshaus, 478 F.2d 615, 630, 647-50 (D.C. Cir. 1973); Portland Cement Ass'n. v. Ruckelshaus, 486 F.2d 375, 390-402 (D.C. Cir. 1973), cert. denied, 417 U.S. 921 (1974); Ethyl Corp. v. EPA, 541 F.2d 1, 48-55 (D.C. Cir.), cert. denied, 426 U.S. 941 (1976).

44. 5 U.S.C. $§ 553$ (1982).

45. Vermont Yankee Nuclear Power Corp. v. Natural Resources Defense Council, Inc., 435 U.S. $519,539-48$ (1978).

46. For a good sampling of views in the debate over informal rulemaking procedures, see Breyer, Vermont Yankee and the Courts' Role in the Nuclear Energy Controversy, 91 HARV. L. REV. 1833 (1978); Byse, Vermont Yankee and the Evolution of Administrative Procedure: A Somewhat Different View, 91 HARV. L. REV. 1823 (1978); Stewart, Vermont Yankee and the Evolution of Administrative Procedure, 91 HARV. L. REV. 1805 (1978). 
(3) In construing the requirements of NEPA, compare Calvert Cliffs ${ }^{47}$ and its progeny, ${ }^{48}$ suggesting the need for "substantive review" of environmental impact statements, with Stryckers' Bay, ${ }^{49}$ reading NEPA as an exclusively procedural mandate.

(4) In the OSHA cost-benefit analysis cases ${ }^{50}$ compare the intra-court differences on what constitutes an adequate administrative record in support of agency-established standards.

Let me develop my position in somewhat greater detail by expanding on one item on this brief list-the cost-benefit cases involving OSHA's promulgation of occupational health standards for benzene and cotton dust. As an initial matter, both raise statutory interpretation issues, namely, whether Congress intended OSHA to set standards requiring the maximum feasible economic and technological investment in promoting health, or standards demanding only a "reasonable" (cost-benefit justified) investment. In Benzene, the plurality avoided the statutory issue by focusing on OSHA's failure to make a threshold finding that the substance created a "substantial risk" of causing cancer at low exposure levels. ${ }^{\text {.1 }}$ In Cotton Dust, a majority of the Justices found the risk substantial and proceeded to read the statute as requiring a maximum feasible investment in health protection. ${ }^{52}$ Most important from our standpoint, however, in both cases once the statutory construction issue was put aside, the Court focused on the rationality of the agency's decisionmaking process.

The Benzene case is a classic example of agency decisionmaking under conditions of scientific uncertainty. OSHA had data clearly indicating that

47. Calvert Cliffs' Coordinating Comm., Inc. v. AEC, 449 F.2d 1109, 1113-15 (D.C. Cir. 1971).

48. See, e.g., Environmental Defense Fund, Inc. v. Corps of Eng'rs, 470 F.2d 289, 300 (8th Cir. 1972); Conservation Council v. Froehlke, 473 F.2d 664, 665 (4th Cir. 1973); Silva v. Lynn, 482 F.2d 1282, 1284-85 (1st Cir. 1973); Sierra Club v. Froehlke, 486 F.2d 946, 951-53 (7th Cir. 1973); Environmental Defense Fund, Inc. v. Corps of Eng'rs, 492 F.2d 1123, 1138-40 (5th Cir. 1974); Environmental Defense Fund, Inc. v. TVA, 371 F. Supp. 1004, 1013-14 (E.D. Tenn.), aff'd per curiam, 492 F.2d 466 (6th Cir. 1974).

49. Strycker's Bay Neighborhood Council, Inc. v. Karlen, 444 U.S. 223, 227-28 (1980).

50. American Textile Mfrs. Inst. v. Donovan, 452 U.S. 490 (1981) (OSHA cotton dust standard); Industrial Union Dep't v. American Petroleum Inst., 448 U.S. 607 (1980) (plurality opinion) (OSHA benzene standard).

51. 448 U.S. at $639-40$.

52. 452 U.S. at 494,509 . The Cotton Dust Court's analysis of the scope of power issue is a prototypical instance of the judicial approach in the Public Interest era. There is no question raised about the agency's substantive authority, as such-that is, no one doubts that the agency has the right to establish workplace safety standards for cotton dust emissions. Moreover, no one questions the legislative authority to mandate the agency to "take" the regulated party's property by assigning costs in excess of the efficient investment in safety-that is, mandating reduction of health hazards to the "maximum extent feasible." Rather, the scope of power issue is whether Congress intended the agency to pursue one legitimate social welfare goal-balancing health concerns against economic costs-or another-promoting health considerations as much as possible. The crucial point is that the analysis of the agency's substantive power is wholly process-oriented; it goes entirely to the question of how the agency ought to weigh competing social values, rather than to the issue of whether the agency can legitimately intrude upon established rights and interests. 
at high exposure levels benzene was a carcinogen. In addition, OSHA had studies indicating that at somewhat lower levels, benzene caused other health hazards. But the agency had no information of harmful effects below a certain emissions level. ${ }^{53}$ The risks did not necessarily disappear. It was simply the case that no existing studies indicated what harm, if any, would occur at relatively low exposure rates.

Under such circumstances, what was the agency's responsibility? The plurality, searching for The Right Answer-through a rather dubious exercise in statutory interpretation-held that OSHA had the burden of meeting a threshold requirement of establishing a "significant risk" before it set any standard at all. Thus, the agency was put to the choice of either producing studies that substantially reduced the scientific uncertainty at lower levels of risk or refraining from setting standards in that zone of potential harm. By contrast, the dissenters, subscribing to a Best Efforts approach, would have required only that the agency provide the best supporting data it could under the circumstances. ${ }^{54}$ Having satisfied themselves that the more lenient standard had been met, the dissenters were, in fact, willing to approve the OSHA standard despite the agency's inability to establish a dose-response curve at low emissions levels. ${ }^{\mathrm{BS}}$

The Cotton Dust case illustrates a similar tension-this time in establishing cost projections of a health standard. Here, the pervasive influence of "uncertainty" is more subtle, but nonetheless at the crux of the contrasting judicial attitudes towards the agency's justificatory responsibilities. The majority opinion, approving OSHA's reliance on an economic feasibility (rather than a cost-benefit) approach, finds adequate support in the administrative record for the established cotton dust standard. Justice Stewart dissents on just this point. The thrust of his disagreement is highly instructive. He argues:

The simple truth about OSHA's assessment of the cost of the Cotton Dust Standard is that the agency never relied on any study or report purporting to predict the cost to industry of the Standard finally adopted by the agency. OSHA did have before it one cost analysis, that of the Research Triangle Institute, which attempted to predict the cost of the final Standard. However, as recognized by the Court, . . . the agency flatly rejected that prediction as a gross overestimate. The only other estimate OSHA had, the Hocutt-Thomas estimate prepared by industry researchers, was not designed to predict the cost of the final OSHA Standard. Rather, it assumed a far less stringent and inevitably far less costly standard for all phases of

53. See 448 U.S. at $634-38$

54. Id. at 707 (Marshall, J., dissenting).

55. Id. at 700 . 
cotton production except roving. ... The agency examined the Hocutt-Thomas study, and concluded that it too was an overestimate of the costs of the less stringent standard it was addressing. I am willing to defer to OSHA's determination that the Hocutt-Thomas study was such an overestimate, conceding that such subtle financial and technical matters lie within the discretion and skill of the agency. But in a remarkable non sequitur, the agency decided that because the Hocutt-Thomas study was an overestimate of the cost of a less stringent standard, it could be treated as a reliable estimate for the more costly final Standard actually promulgated, never rationally explaining how it came to this happy conclusion. This is not substantial evidence. It is unsupported speculation. ${ }^{.6}$

Why did the majority tolerate OSHA's ultimate reliance on the discredited Hocutt-Thomas study? Justice Brennan's opinion is revealing:

The agency itself recognized the problem [with the Hocutt-Thomas study] but found itself limited in the precision of its estimates by the industry's refusal to make more of its own data available. OSHA explained that, "in the absence of the [industry] survey data [of textile mills], OSHA cannot develop more accurate estimates of compliance costs." . . . Since $\S 6(b)(5)$ of the Act requires that the Secretary promulgate toxic material and harmful physical agent standards "on the basis of the best available evidence," 29 U.S.C. $\$ 655(\mathrm{~b})(5)$, and since OSHA could not obtain the more detailed confidential industry data it thought essential to further precision, we conclude that the agency acted reasonably in adopting the Hocutt-Thomas estimate. While a cost estimated based on the standard actually promulgated surely would be preferable, we decline to hold as a matter of law that its absence under the circumstances required the Court of Appeals to find that OSHA's determination was unsupported by substantial evidence. ${ }^{57}$

In essence, Justice Brennan is arguing that the agency did the best it could under the circumstances, and that is all the Court will require. The study OSHA commissioned was botched; the industry-sponsored study was based on limited data and wrong assumptions-all of which was beyond OSHA's control, but in fact about par for the course.

Again scientific uncertainty played a role-albeit indirectly. Because OSHA could not establish a dose-response curve, it had no threshold level of health risk to guide its compliance cost analysis; as a consequence, the Hocutt-Thomas researchers operated on imprecise information about the range of reduction in health risk that the agency was considering. Only

56. 452 U.S. at 542-43 (Stewart, J., dissenting).

57. Id. at 527-29 (majority opinion) (footnotes omitted). 
after OSHA had compliance cost information in hand, did it feel greater confidence about setting an actual target for reduction of risk. And, at that point, a reduction in risk more substantial than that considered by the researchers appeared feasible.

Thus, cost projections, like risk determinations, ultimately turn out to be quite speculative. Agency decisionmaking processes that are premised on an initial evaluation strategy that appears to be highly rational, eventually rely on "best available evidence" and assumptions about a range of more-or-less reasonable scenarios. OSHA could have been instructed to spend two more years and still greater resources on more consulting studies. In the meantime, new epidemiological data and capital investments would cast doubt on the next round of studies. Methodological flaws in the revised analysis would be revealed, and once again the issue would be whether a Demand for Truth or an Assurance of Good Faith should be the ultimate standard. And the Court would most likely divide sharply, as it did in Benzene and Cotton Dust.

I am arguing, then, that the most salient feature of judicial review in the Public Interest era has been the debate over just how intensively the courts ought to monitor agency decisions characterized by various kinds of uncertainty. Returning to our earlier inquiry, how does my analysis relate to the concept of "rights"? Do conventional notions of rights continue to exercise a central influence on judicial thinking in the administrative law of the Public Interest period? In my view, the answer is no. The landmark cases to which I have referred are primarily concerned with bureaucratic processes for reconciling broad collective interests of social groups and industry.

To the extent that rights retain some vestigial importance in Public Interest cases, it is the procedural model that warrants attention. More specifically, when courts oscillate towards a Demand for Truth they sometimes impose on agencies elements of the decisionmaking model that the judiciary has traditionally viewed as best-suited for assuring accuracy in the resolution of conflicting claims: the trial-type hearing. ${ }^{58}$ In the context of a continuing New Deal program, the landmark case of Goldberg $v$. Kelly ${ }^{58}$-involving eligibility determinations in the Aid to Families with Dependent Children program-is a contemporary instance of this point: an effort to utilize what the Court perceived as the best technique for

58. For a good discussion of the elements of the model, see Friendly, "Some Kind of Hearing," 123 U. PA. L. REV. 1267 (1975). Even if the court imposes less than a full-scale trial-type hearing, the model may provide the measuring-stick against which agency processes are evaluated. See Judge Bazelon's opinions in Ethyl Corp. v. EPA, 541 F.2d 1, 66-68 (D.C. Cir.) (en banc) (Bazelon, J., concurring), cert. denied, 426 U.S. 941 (1976), and NRDC v. Nuclear Regulatory Comm., 547 F.2d 633, 643-45 (D.C. Cir. 1976), rev'd and remanded, 435 U.S. 519 (1978).

59. 397 U.S. 254 (1970). 
guarding against administrative error and assuring accuracy. But the impulse to judicialize the administrative process through wholesale infusion of rights analysis has been a weak one on the whole. ${ }^{60}$ And the substantive rights aspect of Goldberg-the New Property notion ${ }^{61}$ - has had no discernible analogical force in the implementation of Public Interest programs. ${ }^{62}$

\section{A Concluding Note}

The paradigm Public Interest cases, dealing with pollution, ecological, health and safety risks, raise concerns about bureaucratic rationality rather than about particularized rights. ${ }^{63}$ As a result, the concept of rights has become of secondary significance-almost lost in a rising tide of concern about a wide variety of techniques for controlling discretion in programs affecting broad-based societal interests. In this milieu, not only the tradition-minded judges of the Populist-Progressive era, but the deferential judiciary of the New Deal as well, seem the product of a strikingly different age.

60. Even in government benefit cases, Goldberg has been limited. See Mathews v. Eldridge, 424 U.S. 319 (1976). And the Goldberg approach has had very little influence on Public Interest cases. But cf. supra note 58 (discussing Judge Bazelon's views).

61. See Reich, The New Property, 73 YALE L.J. 733 (1964).

62. Nonetheless, the New Property conception of substantive rights does retain vitality in government largess cases-albeit not without continuing controversy. I am suggesting, of course, that these perennial cases are not really central to the regulatory concerns that have triggered the most consequential political developments and judicial responses since the mid-1960's.

63. For the classic sociological perspective on the problems of bureaucratic rationality that courts have confronted in steadily increasing volume since the New Deal, see M. WEBER, Bureaucracy, in FROM MAX WEBER: ESSAYS IN SOCIOLOGY 196 (1946). 